Original paper

DOI: $10.2478 /$ agri-2019-0005

\title{
CHARACTERIZATION AND EVALUATION OF BACILLUS SIAMENSIS ISOLATE FOR ITS GROWTH PROMOTING POTENTIAL IN TOMATO
}

\author{
AMANUL ISLAM*, MD. SHAHINUR KABIR, ABUL KHAIR \\ Jahangirnagar University, Savar, Bangladesh
}

ISLAM, A. - KABIR, MD. S. - KHAIR, A.: Characterization and evaluation of Bacillus siamensis isolate for its growth promoting potential in tomato. Agriculture (Polnohospodárstvo), vol. 65, 2019, no. 2, pp. 42-50.

\begin{abstract}
In quest of prospective rizospheric bacteria of agricultural importance, one of the isolates from bean (Lablab niger Medikus) was identified as Bacillus siamensis based on morphological, biochemical and 16S rRNA gene sequencing data. Study was carried out to evaluate growth promotion of two tomato cultivars, in vitro and in vivo. Experiments conducted for two consecutive years, following seed treatments revealed that the bacterial isolate increased plant height by $14.66-15.68 \%$, shoot fresh weight by $34.5-65.09 \%$ and root fresh weight by $75.3-92.48 \%$ over the non-treated control. The bacterial strain showed encouraging results for plant growth promotion in pot study and hence may be useful for the growth enhancement of tomato plant.
\end{abstract}

Key words: 16S rRNA gene, Bacillus siamensis, growth promotion, plant growth-promoting rhizobacteria, tomato

Dependence on chemical inputs are major means of modern day agriculture management, which have created a negative impact on agro-ecosystems. There is an immediate need to minimize the use of hazardous agrochemicals by alternative ways. The utilization of plant growth promoting bacteria as bio-fertiliser offers an attractive option to replace synthetic chemical fertiliser, pesticides and supplements. Rhizobacteria, that live in the plant rhizosphere play a vital role in maintaining soil quality and upgrading plant growth and development. Various plant growth-promoting rhizobacterial (PGPR) strains such as Bacillus, Pseudomonas, Azotobacter, Azospirillum spp. are being used to develop organic biofertilisers. PGPR promote plant growth through nutrient recycling, nitrogen fixation, synthesis of the phytohormone, solubilization of nutrients such as $\mathrm{P}, \mathrm{K}$ and $\mathrm{Fe}$, and enhancing plant resistance to pests and diseases (Alan \& Kiran 2018).
Commercial applications of PGPR are being investigated and researchers are able to use them successfully as inoculants from laboratory to field (Sivasakthi et al. 2014). There are fewer than 20 different PGPR strains which are known to be available commercially (Kloepper et al. 2004). Commercialization efforts have been hampered due to variable strain performance. However, effective PGPR number can be increased by isolating promising native strains, which are more suitable as bio-inoculants due to a better environmental adaptation (Sicuia et al. 2015). Considering the beneficial roles of PGPR in sustainable agricultural systems, it would be very economical to search and document prospective native isolates.

Tomato is an important vegetables in Bangladesh. Currently, tomato ranks first in respect of production and second in respect of area from all vegetables grown in the country (BBS 2016). To meet up local demand, Bangladesh government imported

Amanul Islam (*Corresponding author), Md. Shahinur Kabir, Abul Khair, Department of Botany, Jahangirnagar University, Savar, Dhaka-1342, Bangladesh. E-mail: progoti17@gmail.com 
$28,76,613$ metric tons of tomato from foreign countries in the year 2014-2015 (BBS 2016). Considering the country's limited arable areas for vegetables, studies about eco-friendly farming systems is necessary to achieve increase of production in order to keep pace with increasing population in the country. In this context of Bangladesh with emphasis in tomato crop, the present study was made to find promising native rhizospheric bacterial isolates as a plant growth promoter so that it could contribute to biofertilisation.

The goal of the work was to search prospective bacterial isolate from agricultural fields which can be used to develop as environment-friendly biofertiliser for tomato plants cultivated in different agro-ecological zones (AEZ) of Bangladesh. The specific aim of the present work was to evaluate the growth promotion potentiality of tomato plant using a bacterium isolated from bean rhizosphere.

\section{MATERIAL AND METHODS}

Sample collection and isolation of bacteria from the rhizosphere

Bean (Lablab niger Medikus) rhizosphere soil samples along with the roots were collected from a farmer's field located in Nobinagar, Brahmanbaria district, Bangladesh. The isolate was obtained from rhizosphere soil from old Meghna estuarine floodplain agro-ecological zone (AEZ) of Bangladesh and the soil belongs to predominantly silty, but silty clay and clay also found. Soil samples were air dried and brought to room temperature $\left(28 \pm 1{ }^{\circ} \mathrm{C}\right)$. One gram of each of the collected soil were weighed and placed in the test tube containing $9 \mathrm{~mL}$ of $0.9 \% \mathrm{NaCl}$ solution (Bahig et al. 2008). The suspension was serially diluted and $0.1 \mathrm{ml}$ of an appropriately diluted culture was spread onto the nutrient agar (NA; containing g/l: $3 \mathrm{~g}$ Beef extract, $5 \mathrm{~g}$ Peptone, $15 \mathrm{~g}$ Agar) plates to isolate rhizobacteria from soil. The nutrient agar plates were incubated at $28 \pm 2^{\circ} \mathrm{C}$ for $24 \mathrm{~h}$. After incubation of the inoculated plates, various types of bacterial colonies were developed. Bacterial colonies of different morphology were randomly selected and purified. One of the isolates was designated as Pbbb1 and selected for further study.

\section{Characterization of the isolate Pbbbl}

Morphological and biochemical tests were carried out to characterize the bacterial isolate Pbbb1 by using standard procedures (Schaad et al. 2001) such as Gram-staining reaction, catalase activity, oxidase activity, nitrate reduction, arginine decarboxylase activity, gelatin liquefaction, urease activity, levan formation from sucrose and utilization of glucose, maltose, lactose, xylose and mannitol. Results of these tests were scored as either positive or negative. Growth parameters of bacterial isolate were studied using nutrient broth (NB) under various $\mathrm{NaCl}$ concentrations, varying temperatures and pH using a turbidometric method (Chookietwattana $\&$ Maneewan 2012). Growth rate $(\mu)$, doubling time $\left(\mathrm{t}_{\mathrm{d}}\right)$ and multiplication rate (MR) of the Pbbbl was calculated according to Painter and Marr (1968) and Stanier et al. (1970), respectively.

Production of extracellular hydrolytic enzymes such as protease, cellulase and amylase, were tested by growing Pbbb1 on the medium containing enzyme substrate; skim milk for protease assay (Maurhofer et al. 1995), carboxymethyl cellulose for cellulase assay (Shivakumar et al. 2013) and starch for amylase assay (Schaad et al. 2001). Development of halo zone surrounding the colony was considered as positive result. HCN production was determined using Bakker and Schippers (1987) method. Siderophore production was tested using method described by Naik et al. (2008). The ability of the bacteria to grow in $\mathrm{N}$-free medium was determined following the methodology of Kumar et al. (2012). Isolate was streaked on sterile Norris Agar plate. The method described by Silva et al. (2003) was used to determine root colonization bioassay.

\section{SrRNA sequencing for identification of Pbbb1}

Genomic DNA of Pbbb1 was isolated from the bacterial colony using Maxwell Cell Kit (Promega, USA) and Maxwell 16 automated DNA extractor following manufacturer's instructions. The purity and DNA concentration was measured using a NanoDrop Spectrophotometer (Thermo Scientific, U.S.A.). The $16 \mathrm{~S}$ rRNA gene was amplified by polymerase chain reaction (PCR) using the primer pair 1492R (5'-GGTTACCTTGTTACGACTT-3') and 27F(5'-AGAGTTTGATCMTGGCTCAG-3'). DNA concentration of the sample was $197.2 \mathrm{ng} / \mu \mathrm{l}$. Ampli- 
fication reactions were performed in a total volume of $25 \mu \mathrm{l}$ containing $1 \mu \mathrm{l}(60 \mathrm{ng})$ of DNA template, $1 \mu \mathrm{l}$ of each forward and reverse primer $(10 \mu \mathrm{M})$, 9.5 $\mu 1$ water and $12.5 \mu 1$ Master Mix (Promega, USA). To amplify the target region, thermal cycling was performed as follows: initial denaturation at $95^{\circ} \mathrm{C}$ for $4 \mathrm{~min}$, followed by 30 cycles in which each cycle consists of denaturation at $95^{\circ} \mathrm{C}$ for $30 \mathrm{~s}$, annealing at $49^{\circ} \mathrm{C}$ for $30 \mathrm{~s}$, followed by extension at $72^{\circ} \mathrm{C}$ for $1 \mathrm{~min} 25 \mathrm{~s}$. The final extension was done at $72^{\circ} \mathrm{C}$ for $5 \mathrm{~min}$. These reactions were carried out using a thermocycler (Gene Atlas, Astesc, Japan). The PCR product was resolved by electrophoresis in 1\% agarose $(\mathrm{w} / \mathrm{v})$ gel submerged in $1 \times \mathrm{TAE}$ buffer. The amplified DNA band was visualized using a transilluminator after staining with ethidium bromide. The PCR product was sequenced in both directions at 1st Base Laboratories, Malaysia. The sequence obtained was used as a query sequence to identify the bacterial isolate by using EZBioCloud (https:// www.ezbiocloud.net/) identification tool (Yoon et al. 2017). The $16 \mathrm{~S}$ rRNA gene sequence of the bacterial isolate was deposited to GenBank and accession number was obtained (MH458894).

For phylogenetic analysis, the 16S rRNA gene sequences were aligned with the Clustal $\mathrm{W}$ and the tree was constructed with the maximum likelihood method based on the Tamura-Nei model (Tamura \& Nei 1993) integrated in the MEGA7 software (Kumar et al. 2016). The phylogenetic tree was tested with 1,000 bootstrap replicates.

\section{Effect of selected bacterial isolate on plant growth} parameters of tomato

Plant growth promotional efficacy of Pbbb1 isolate was evaluated in tomato. Tomato cultivars Ratan and Pusa Ruby were used in this study because of popularity of these cultivars among Bangladeshi farmers. Seed surface sterilization and water formulated bacterial inoculation was followed as described by Weller \& Cook (1983). Seed samples were soaked in cell suspension of Pbbb1 isolate at concentration of approximately $1 \times 10^{8} \mathrm{cfu} / \mathrm{ml}$. Seedling vigor test was performed using the standard roll towel method (ISTA 1999). Treated and untreated seeds placed equidistantly in between two wet paper towels and the papers were rolled. Seeds were allowed to germinate at $25^{\circ} \mathrm{C}$. After 10 days of incuba- tion seedlings were measured for (a) seed percentage germination (b) root length (c) shoot length (d) seedling weight and (e) vigor index were calculated. The vigor index of the seedling was calculated by using the following formula (ISTA 1999):

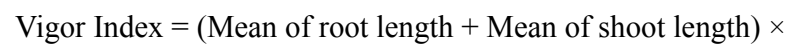

For a pot experiment the bacterial isolate was tested in sterilized soil. Pot experiment was performed in soil (clay $87 \%$, loam $13 \%$ and sand $<1 \%$ ) of Madhupur tract AEZ. The experiment was carried out at the experimental site of Botanical Gar-

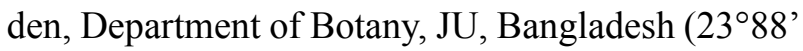
$\mathrm{N}$ and $90^{\circ} 26^{\prime} \mathrm{E}$ ) during two successive local crop seasons (December 2015 to February 2016 and December 2016 to February 2017). For pot experiments soil was prepared and sterilized following the method described by Khalequzzaman et al. (2002). Bacterial inoculation was done as described earlier. Control consists of nonbacterized seed. Seeds inoculated with the isolate and without the isolate were permitted to air dry for $6 \mathrm{hrs}$ before planting. Seeds were then sown in earthen pots (diameter: $31 \mathrm{~cm}$, height: $31 \mathrm{~cm}$ ).

The pots were arranged in randomized manner and three plants grown per pot. Three replications were maintained for each treatment. The tomato crop was raised for 90 days. There after the crop was uprooted. The growth parameters namely plant height, number of leaves, leaf area, shoot fresh weight, shoot dry weight, root fresh weight and root dry weight of plants raised from treated and untreated seeds were recorded. The estimation of total chlorophyll was determined according to Arnon (1949):

Total Chlorophyll $=\frac{(20.2 \times \text { OD645 })+(8.02 \times \text { OD663 }) \times \mathrm{V}}{(\mathrm{d} \times 1000 \times \mathrm{W})}$

where:

D - optical density at wavelength indicated; V - final volume of extract; $\mathrm{W}$ - fresh weight of leaf material used; $\mathrm{d}$ - length of light path in $\mathrm{cm}$.

The values were expressed as $\mathrm{mg} / \mathrm{g}$ of the fresh leaf weight.

\section{Statistical analysis}

Data were analyzed for significant mean differences using two-way analysis of variance (ANOVA). Means were separated using Duncan's multi- 
ple range test (DMRT; $\alpha=0.05)$ using SPSS software.

\section{RESULTS AND DISCUSSION}

In this study an isolate was tested for growth promotional efficacy under different conditions during the winter crop growing season for two successive years. The present work also focused on native rhizospheric bacterial isolate. Because co-existence for many years with the natural soil, microbiota should provide native microorganisms with competitive advantages compared to exotic species (Figueroa-López et al. 2016).

\section{Molecular identification of isolated bacteria}

The isolate Pbbb1 obtained from the rhizosphere of bean was characterized morphologically, biochemically and subjected to 16S rRNA gene sequence analysis. The study revealed that isolate Pbbbl is Gram positive and appeared as rod shaped (Figure 1). Colony was small, irregular, round yellowish white on NA medium. Results of biochemical characterization (Table 1) indicated that Pbbb1 was positive for oxidase test, gelatin liquefaction and arginine decarboxylase activity. The isolate could utilize lactose and xylose. Specific growth rate, doubling time and multiplication rate of the isolate in nutrient broth were $0.0099 / \mathrm{h}, 69.59 \mathrm{~min}$ and $0.0143 / \mathrm{h}$, respectively. With respect to protease activity, siderophore production and root colonization by Pbbb1 was found positive (Table 1).

The isolated bacteria was further identified at the molecular level. The comparative 16S rRNA gene sequence-based identification using EZBioCloud bioinformatics tool revealed that the $16 \mathrm{~S}$ rRNA gene of the isolate is $99.72 \%$ identical to that of Bacillus siamensis KCTC 13613 (T). The result of molecular analyses was consistent with the morphological, biochemical and physiological traits of the isolate. Results on the biochemical reactions performed in this study such as nitrate reduction, oxidase, catalase, arginine test, gelatin liquefaction, certain carbohydrate utilizations and morphological features were similar to the result reported by Almoneafy et al. (2012) and Ambawade \& Pathade (2015). Based on the studies conducted, the bacterial isolate was identified as Bacillus siamensis.

Bacillus spp. are well known rhizosphere residents of many crops. The occurrence and isolation of Bacillus species from the rhizosphere of differ-

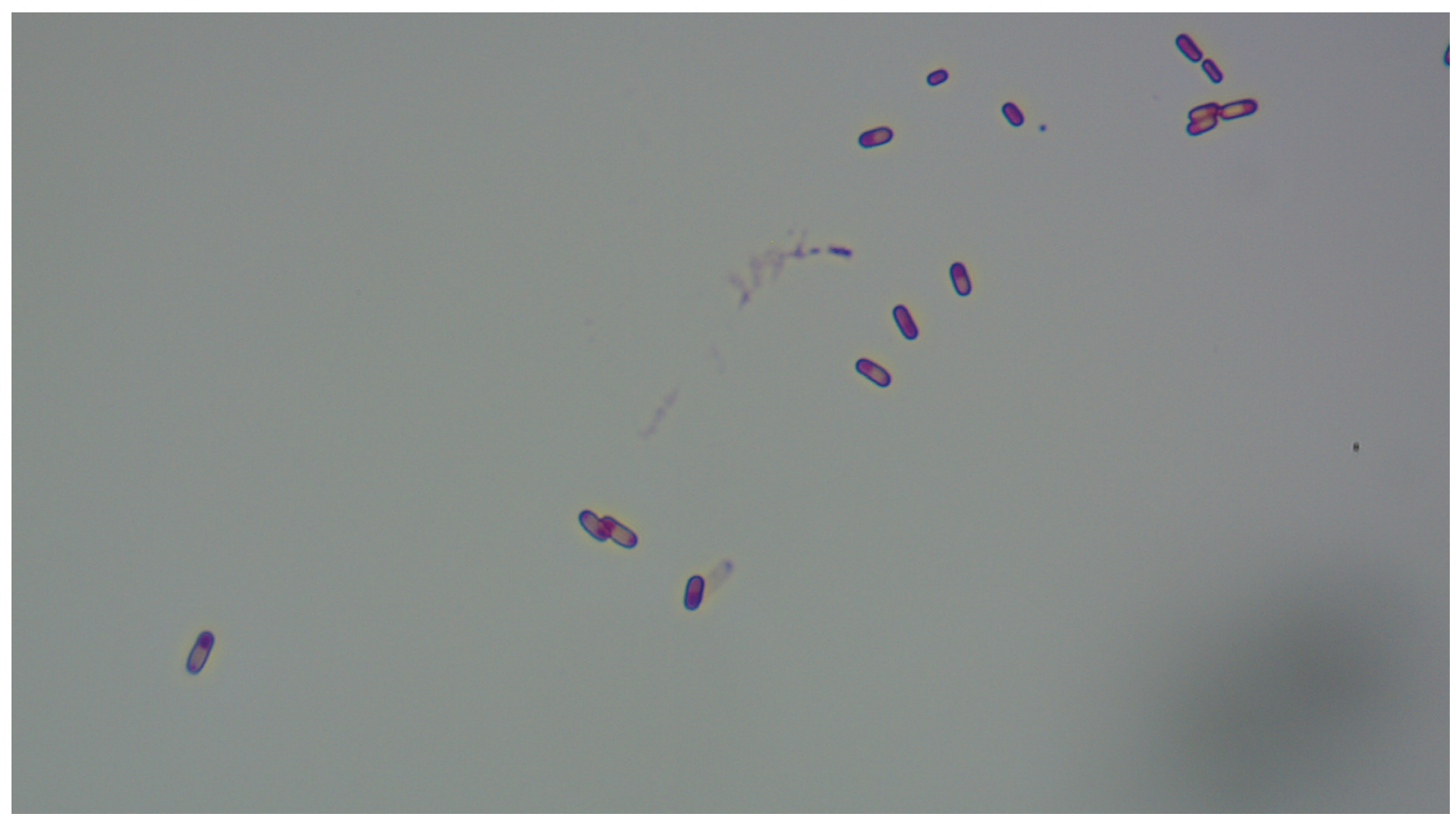

Figure 1. Microscopic image showing cells of isolate Pbbb1 
ent plants have been reported by different authors (Cabra et al. 2017; Almoneafy et al. 2012). This is probably the first report of isolation of $B$. siamensis from Bean rhizospheric soil of Bangladesh. However, information on B. siamensis as a growth promoting microorganism is scanty. Being considered as safe microorganism and holding the remarkable abilities of synthesizing a vast array of beneficial substances (Stein 2005) we targeted Bacillus as the chosen bacterial species.

\section{Effect on the growth of tomato seedlings}

In the present study, the ability of $B$. siamensis for promotion of tomato plant growth was investigated in vitro using the standard roll towel method. The bacterial seed treatment did not significantly decrease or increase the germination percentage. Under laboratory conditions, isolate was able to promote seedling growth and enhance vigor index. The effect was more pronounced in cv. Ratan (Table 2).

$\mathrm{T}$ a $\mathrm{b} \quad 1$ e 1

Biochemical, physiological characterization and beneficial traits of isolate Pbbb1

\begin{tabular}{|c|c|}
\hline Physiochemical indices & Characteristics \\
\hline \multicolumn{2}{|l|}{ Physiological characteristics: } \\
\hline Growth in $\mathrm{NaCl}$ at concentration $(1-5 \%)$ & + \\
\hline Growth at different temperature $\left(20-41^{\circ} \mathrm{C}\right)$ & + \\
\hline Growth at different $\mathrm{pH}(6-8)$ & + \\
\hline Growth on nitrogen free medium & - \\
\hline \multicolumn{2}{|l|}{ Biochemical tests: } \\
\hline Gram reaction & + \\
\hline Oxidase test & + \\
\hline Catalase test & - \\
\hline Gelatin liquefaction & + \\
\hline Nitrate reduction & - \\
\hline Argininedecarboxylase activity & + \\
\hline Levan formation & - \\
\hline Urease test & - \\
\hline \multicolumn{2}{|l|}{ Carbon sources utilization: } \\
\hline Glucose, Maltose, Mannitol & - \\
\hline Lactose, Xylose & + \\
\hline \multicolumn{2}{|c|}{ Secondary metabolites production and beneficial traits: } \\
\hline Starch hydrolysis test & - \\
\hline Protease activity & + \\
\hline Cellulase activity & - \\
\hline HCN production & - \\
\hline Siderophore production & + \\
\hline Root colonization test & + \\
\hline
\end{tabular}

‘+'indicates positive; '-'indicates negative 
The mean shoot length was increased in bacteria treated cv. Pusa Ruby $(10.3 \mathrm{~cm}), \mathrm{cv}$. Ratan $(9.92 \mathrm{~cm})$ and lowest in control. The mean root length was increased in treated cv. Ratan $(11.02 \mathrm{~cm})$, cv. Pusa Ruby $(7.82 \mathrm{~cm})$, and lowest in control. Fresh weight also increased in bacterial treated germinating seedlings. Inoculation enhanced the vigor index when compared to control in cultivar Ratan. However, no significative difference was observed between treatments in the cultivar Pusa Ruby. Similar pattern of

$\mathrm{T}$ a $\mathrm{b} 1$ e 2

The effect of bacterization of tomato seeds with Pbbb1 on seedling vigor of tomato seedling under in vitro conditions (as described by ISTA 1999)

\begin{tabular}{|l|l|c|c|c|c|}
\hline \multicolumn{2}{|l|}{ Treatments } & $\begin{array}{c}\text { Shoot length } \\
{[\mathrm{cm}]}\end{array}$ & $\begin{array}{c}\text { Root length } \\
{[\mathrm{m}]}\end{array}$ & $\begin{array}{c}\text { Fresh weight } \\
{[\mathrm{g}]}\end{array}$ & Vigor index \\
\hline $\begin{array}{l}\text { Pusa } \\
\text { Ruby }\end{array}$ & Pbbb1 & $10.3 \pm 0.33^{\mathrm{a}}$ & $7.82 \pm 0.20^{\mathrm{a}}$ & $0.04 \pm 0.00^{\mathrm{ab}}$ & $1195.92 \pm 29.47^{\mathrm{a}}$ \\
\hline \multirow{2}{*}{ Ratan } & Control & $6.36 \pm 0.64^{\mathrm{b}}$ & $6.72 \pm 0.25^{\mathrm{a}}$ & $0.02 \pm 0.00^{\mathrm{b}}$ & $1255.68 \pm 51.10^{\mathrm{a}}$ \\
& Pbbb1 & $9.92 \pm 0.40^{\mathrm{ab}}$ & $11.02 \pm 1.54^{\mathrm{a}}$ & $0.04 \pm 0.00^{\mathrm{ab}}$ & $1633.32 \pm 134.70^{\mathrm{a}}$ \\
& Control & $9.00 \pm 0.70^{\mathrm{b}}$ & $7.70 \pm 0.58^{\mathrm{b}}$ & $0.03 \pm 0.00^{\mathrm{b}}$ & $1302.6 \pm 45.48^{\mathrm{b}}$ \\
\hline
\end{tabular}

Values are the means $( \pm$ SE) of three replications. Means in a column with similar letter(s) are not significantly different at 0.05 level according to Duncan Multiple Range Test

$\mathrm{T}$ a $\mathrm{b} 1$ e 3

Effect of bacterial isolate on growth parameters of tomato plants under pot conditions in cv. Pusa Ruby

\begin{tabular}{|c|c|c|c|c|c|c|c|c|c|c|}
\hline \multicolumn{2}{|c|}{ Bacterial Treatment } & $\begin{array}{l}\text { Height } \\
{[\mathrm{cm}]}\end{array}$ & $\begin{array}{c}\text { Leaf area } \\
{\left[\mathrm{cm}^{2}\right]}\end{array}$ & $\begin{array}{c}\text { Leaves } \\
\text { no./plant }\end{array}$ & $\begin{array}{l}\text { Root length } \\
\quad[\mathrm{cm}]\end{array}$ & $\begin{array}{c}\text { Root fresh } \\
\text { weight } \\
\text { [g/plant }]\end{array}$ & $\begin{array}{c}\text { Shoot fresh } \\
\text { weight } \\
\text { [g/plant }] \\
\end{array}$ & $\begin{array}{c}\text { Root dry } \\
\text { weight } \\
\text { [g/plant] }\end{array}$ & $\begin{array}{c}\text { Shoot dry } \\
\text { weight } \\
\text { [g/plant] }\end{array}$ & $\begin{array}{c}\text { Total } \\
\text { chlorophyll } \\
{[\mathrm{mg} / \mathrm{g}]} \\
\end{array}$ \\
\hline \multirow{2}{*}{$2015-16$} & Unin & $52 \pm 2.00^{\mathrm{b}}$ & $150 \pm 3.93^{\mathrm{b}}$ & $44 \pm 3.05^{\mathrm{b}}$ & $11.1 \pm 2.08^{\mathrm{b}}$ & $8.25 \pm 0.57^{\mathrm{ab}}$ & $37.45 \pm 3.46^{\mathrm{b}}$ & $3.59 \pm 1.52^{\mathrm{a}}$ & $6.09 \pm 1.00^{\mathrm{b}}$ & $1.97 \pm 0.57^{\mathrm{a}}$ \\
\hline & Pbbb1 & $62 \pm 6.42^{\mathrm{ab}}$ & $374 \pm 4.16^{\mathrm{a}}$ & $68 \pm 2.64 \mathrm{a}^{\mathrm{a}}$ & $22.1 \pm 0$ & $9.70 \pm 1$ & 60.36 & $4.23=$ & 17.9 & $1.91 \pm 0.57^{\mathrm{a}}$ \\
\hline \multirow{2}{*}{$2016-17$} & Uninoculated & $53 \pm 1.52^{b}$ & $396 \pm 5.34^{\mathrm{a}}$ & $20 \pm 1.15^{\mathrm{b}}$ & $15 \pm 2.30^{\mathrm{a}}$ & $3.59 \pm 0.57^{\mathrm{b}}$ & $61.25 \pm 4.01^{\mathrm{b}}$ & $2.6 \pm 0.57^{\mathrm{a}}$ & $28.25 \pm 4.93^{\mathrm{a}}$ & $1.21 \pm 0.57^{\mathrm{a}}$ \\
\hline & Pbbb1 & $60 \pm 2.00^{\mathrm{ab}}$ & $450 \pm 3.83^{\mathrm{a}}$ & $41 \pm 3.21^{\mathrm{a}}$ & $14.6 \pm 2.08^{\mathrm{a}}$ & $9.60 \pm 2.88^{\mathrm{a}}$ & $103.52 \pm 6.92^{\mathrm{a}}$ & $6.20 \pm 2.00^{\mathrm{a}}$ & $37.5 \pm 10.40^{\mathrm{a}}$ & $0.69 \pm 0.00^{\mathrm{a}}$ \\
\hline
\end{tabular}

Values are the means $( \pm \mathrm{SE})$ of three replications. Means in a column with similar letter(s) are not significantly different at 0.05 level according to Duncan Multiple Range Test

$\mathrm{T}$ a b 1 e 4

Effect of bacterial isolate on growth parameters of tomato plants under pot conditions in cv. Ratan

\begin{tabular}{|c|c|c|c|c|c|c|c|c|c|c|}
\hline \multicolumn{2}{|c|}{ Bacterial Treatment } & $\begin{array}{l}\text { Height } \\
{[\mathrm{cm}]}\end{array}$ & $\begin{array}{l}\text { Leaf area } \\
{\left[\mathrm{cm}^{2}\right]}\end{array}$ & $\begin{array}{c}\text { Leaves } \\
\text { no./plant }\end{array}$ & $\begin{array}{c}\text { Root } \\
\text { length } \\
{[\mathrm{cm}]} \\
\end{array}$ & $\begin{array}{l}\text { Root fresh } \\
\text { weight } \\
\text { [g/plant] }\end{array}$ & $\begin{array}{c}\text { Shoot fresh } \\
\text { weight } \\
\text { [g/plant }]\end{array}$ & $\begin{array}{l}\text { Root dry } \\
\text { weight } \\
\text { [g/plant] }\end{array}$ & $\begin{array}{l}\text { Shoot dry } \\
\text { weight } \\
\text { [g/plant] }\end{array}$ & $\begin{array}{c}\text { Total } \\
\text { chlorophyll } \\
{[\mathrm{mg} / \mathrm{g}]} \\
\end{array}$ \\
\hline \multirow{2}{*}{$2015-16$} & Uninoculated & $61 \pm 4.04^{b}$ & $215 \pm 8.54^{\mathrm{b}}$ & $37 \pm 4.16^{\mathrm{b}}$ & $20 \pm 1.00^{\mathrm{a}}$ & $3.25 \pm 0.57^{\mathrm{b}}$ & $40.4 \pm 1.70^{\mathrm{a}}$ & $1.43 \pm 0.57^{\mathrm{a}}$ & $7.04 \pm 1.15^{\mathrm{a}}$ & $1.67 \pm 0.57^{\mathrm{a}}$ \\
\hline & Pbbb1 & $72 \pm 3.46^{\mathrm{ab}}$ & $340 \pm 1.10^{\mathrm{a}}$ & $80 \pm 2.88^{\mathrm{a}}$ & $21.1 \pm 6.00^{\mathrm{a}}$ & $6.38 \pm 1.89^{\mathrm{a}}$ & $62.10 \pm 2.51^{\mathrm{a}}$ & $3.94 \pm 2.00^{\mathrm{a}}$ & $12.91 \pm 2.08^{\mathrm{a}}$ & $1.29 \pm 0.00^{\mathrm{a}}$ \\
\hline \multirow{2}{*}{$2016-17$} & Uninoculated & $60 \pm 1.73^{\mathrm{b}}$ & $486 \pm 7.81^{\mathrm{a}}$ & $29 \pm 1.52^{\mathrm{a}}$ & $14.9 \pm 2.51^{\mathrm{a}}$ & $11.34 \pm 2.51^{\mathrm{ab}}$ & $52.32 \pm 5.56^{\mathrm{a}}$ & $8.25 \pm 2.00^{\mathrm{a}}$ & $9.71 \pm 1.73^{b}$ & $1.69 \pm 0.57^{\mathrm{a}}$ \\
\hline & Pbbb1 & $68 \pm 0.57^{\mathrm{a}}$ & $504 \pm 9.39^{\mathrm{a}}$ & $35 \pm 4.16^{\mathrm{a}}$ & $13.9 \pm 2.64^{\mathrm{a}}$ & $17.5 \pm 2.64^{\mathrm{a}}$ & $70.62 \pm 9.00^{\mathrm{a}}$ & $7.93 \pm 3.00^{\mathrm{a}}$ & $18.71 \pm 7.00^{\mathrm{a}}$ & $0.71 \pm 0.71^{\mathrm{a}}$ \\
\hline
\end{tabular}

Values are the means $( \pm \mathrm{SE})$ of three replications. Means in a column with similar letter(s) are not significantly different at 0.05 level according to Duncan Multiple Range Test 
improved seedling growth of tomato plants by $B a-$ cillus was earlier reported by Cabra et al. (2017). Present results agreed with Alam et al. (2003), who reported the cultivar variation in the stimulation of rice growth inoculated with plant growth-promoting bacteria. Different species or cultivars may produce different types of root exudates, which may support the activity of the inoculums or serve as substrate for the formation of biologically active substances by the inoculums (Khalid et al. 2004).

Growth promotion potentiality of the bacterial isolate under pot culture conditions

The data presented in the Table 3 and 4 showed that in pot experiment $B$. siamensis inoculated tomato seeds influenced plant height, number of leaves, leaf area, root length, shoot fresh weight, shoot dry weight, root fresh weight, root dry weight of both tomato cultivars. However, there were differences in growth promotion between the two cultivars. Inoculation increased plant height by $14.66 \%$ in $\mathrm{cv}$. Pusa Ruby and $15.68 \%$ in cv. Ratan over the control plants. Similarly root length increased by $49.54 \%$ in cultivar Pusa Ruby and $2.5 \%$ in cv. Ratan relative to the control. In case of Pusa Ruby shoot fresh weight increased by $65.09 \%$ and $34.5 \%$ in cv. Ratan over the control. As compared to control root fresh weight increment recorded $92.48 \%$ in cv. Pusa Ruby and $75.31 \%$ in cv. Ratan as compared to the control. Dry matter content also increased in both the cultivars. Increased number of leaves, leaf area was also observed in comparison to the control. No significant differences were seen between the treated and untreated control in respect of chlorophyll content.

A recent study (Ambawade \& Pathade 2018) indicated that $B$. siamensis isolated from wild banana rhizosphere is capable to produce Indole acetic acid (IAA) which is one of the most significant physiologically active phytohormone. In general, the bacterial isolate significantly increased root length, shoot length and exhibited biomass increment in the treated tomato cultivars, which is in concordant with the results obtained in earlier studies conducted with the Bacillus strains (Almoneafy et al. 2014; Sana et al. 2014).

The increase in shoot and root growth, number of leaves, leaf area, dry matter production in response to $B$. siamensis may be attributed to the synthesis of phytohormones, increased uptake and availability of nutrients, biocontrol abilities, and triggering plant

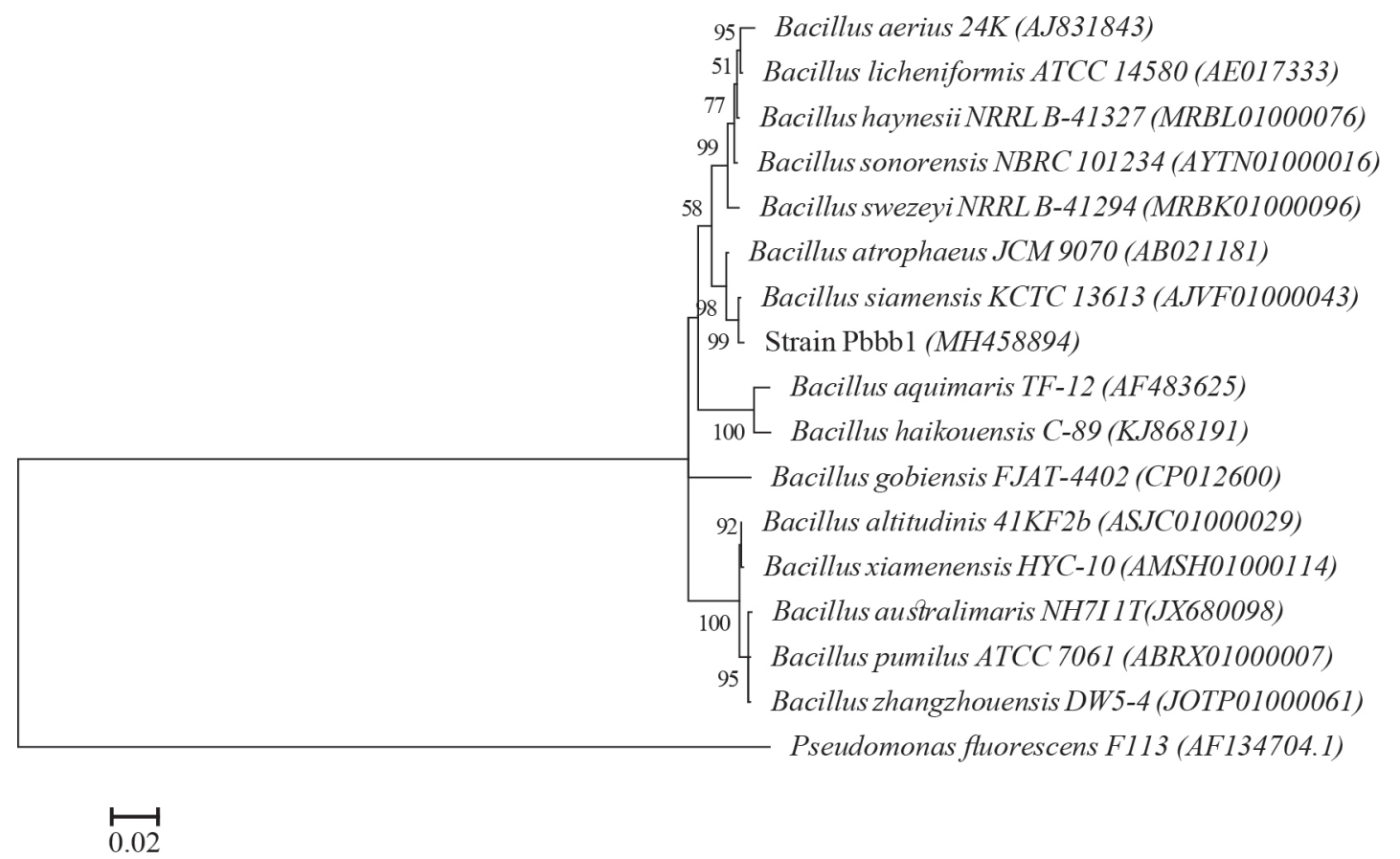

Figure 2. Phylogenetic tree showing position of the bacterial isolate used in this study. The 16S rDNA sequences were aligned with the ClustalW and the tree was constructed with the maximum likelihood method based on the Tamura-Nei model integrated in the MEGA7 software. The GenBank accession numbers of the DNA sequences are shown in parentheses. 
resistance (Figueiredo et al. 2016). Application of Bacillus species to seeds or roots has been shown to cause alteration in the composition of rhizosphere microflora leading to increase in growth of plants (Vessey \& Buss 2002).

\section{CONCLUSIONS}

The results of this study demonstrated that the bacterial strain $B$. siamensis Pbbb1 has the potential to positively influence the growth and development of tomato plant. The isolate was obtained from a single AEZ of the country but it may be useful in tomato crop fields of other AEZs. Further work on the response of other crops to this bacterium need to be evaluated.

\section{REFERENCES}

ALAM, M.S. - CUI, Z. - YAMAGISHI, T. - ISHI, R. 2003. Rice cultivar variation in the growth response to inoculation of free-living rhizobacteria. In Plant Production Science, vol. 6, pp. 50-51.

ALAN, C.G. - KIRAN, R.G. 2018. Plant growth-promoting rhizobacteria promote plant size inequality. In Scientific REPORTs, vol. 8, pp. 13828. DOI: 10.1038/s41598-01832111-z.

ALMONEAFY, A. - XIE, G.L. - TIAN, W.X. - XU, L.H. - ZHANG, G.Q. - IBRAHIM, M. 2012. Characterization and evaluation of Bacillus isolates for their potential plant growth and biocontrol activities against tomato bacterial wilt. In African Journal of Biotechnology, vol. 11 , no. 28 , pp. $7193-7201$.

ALMONEAFY, A.A. - KAKAR, K.U. - LI, B. - SAAND, M.A. - CHUN-1AN, Y. - XIE, G.L. 2014. Tomato plant growth promotion and antibacterial related-mechanisms of four rhizobacterial Bacillus strains against Ralstonia solanacearum. In Symbiosis, vol. 63, no. 2, pp. 59-70. DOI: 10.1007/s13199-014-0288-9.

AMBAWADE, M.S. - PATHADE, G.R. 2018. Indole Acetic Acid (IAA) Production by Bacillus siamensis BE 76 isolated from Musa balbisiana (Banana). In Journal of Chemical and Pharmaceutical Research, vol. 10, no. 2, pp. 610.

AMBAWADE, M.S. - PATHADE, G.R. 2015. Production of gibberellic acid by Bacillus siamensis BE 76 isolated from banana plant (Musa spp.). In International Journal of Science and Research, vol. 4, no. 7, pp. 394-398.

ARNON, D.I. 1949. Copper enzymes in isolated chloroplasts polyphenol oxidase in Beta vulgaris. In Plant Physiology, vol. 24, no. 1, pp. 1-15.

BAHIG, A.E. - ALY, E.A. - KHALED, A.A. - AMEL, K.A. 2008. Isolation, characterization and application of bacterial population from agricultural soil at Sohag Province, Egypt. In Malaysian Journal of Microbiology, vol. 4 , no. 2 , pp. $42-50$

BAKKER, A.W. - SCHIPPERS, B. 1987. Microbial cyanide production in the rhizosphere in relation to potato yield reduction and Pseudomonas spp. mediated plant growth stimulation. In Soil Biology and Biochemistry, vol. 19, pp. 451-457. DOI: 10.1016/0038-0717(87)90037-X

BBS (Bangladesh Bureau of Statistics). 2016. Yearbook of Agricultural Statistics-2015. Bangladesh Bureau of Statistics, Ministry of Planning, Government of the People's Republic of Bangladesh.

CABRA, C.T. - GONZALEZ, C.A.R. - CUASQUER, C.P.V. - ALZATE, O.A.T. - RODRIGUEZ, A.H. 2017. Bacillus effect on the germination and growth of tomato seedlings (Solanum lycopersicum L). In Acta Biológica Colombiana, vol. 22, no. 1, pp. 37-44.

CHOOKIETWATTANA, K. - MANEEWAN, K. 2012. Selection of efficient salt-tolerant bacteria containing ACC deaminase for promotion of tomato growth under salinity stress. In Soil and Environment, vol. 31, no. 1, pp. $30-36$.

FIGUEIREDO, Md. V.B. - BONIFACIO, A. - RODRIGUES, A.C. - ARAUJO, F.Fde. 2016. Plant growth-promoting rhizobacteria: Key mechanisms of action. In CHOUDHARY, D.K. (Ed.) - VARMA, A. Microbial-mediated induced systemic resistance in plants. Singapore: Springer, pp. 27-33. DOI: 10.1007/978-981-10-0388-2 3 .

FIGUEROA-LOPEZ, A.M. - CORDERO-RAMIREZ, J.D. - MARTINEZ-ÁLVAREZ, J.C. - LOPEZ-MEYER, M. LIZARRAGA-SANCHEZ, G.J. - FELIX-GASTELUM, R. - CASTRO-MARTINEZ, C. - MALDONADO-MENDOZA, I.E. 2016. Rhizospheric bacteria of maize with potential for biocontrol of Fusarium verticillioides. In Springer Plus, vol. 5, pp. 330. DOI: 10.1186/s40064016-1780-x.

ISTA. 1999. International rules for seed testing. In Seed Science and Technology, vol. 27, Supplement rules, pp. $27-31$.

KHALEQUZZAMAN, K.M. - JINNAH, M.A. - RASHID, M.A.A.M. - CHOWDHURY, M.N.A. - ALAM, M.M. 2002. Effect of Pseudomonas fluorescens in controlling bacterial wilt of tomato. In Plant Pathology Journal, vol. 1, pp. $71-73$.

KHALID, A. - ARSHAD, M. - ZAHIR, Z.A. 2004. Screening plant growth-promoting rhizobacteria for improving growth and yield of wheat. In Journal of Applied Microbiology, vol. 96, pp. 473 -480. DOI:10.1046/j.13652672.2003.02161.x

KLOEPPER, J.W. - RYU, C.M. - ZHANG, S. 2004. Induced systemic resistance and promotion plant growth by $\mathrm{Ba}$ cillus spp. In Phytopathology, vol. 94, pp. 1259-1266.

KUMAR, P. - DUBEY, R.C. - MAHESHWARI, D.K. 2012. Bacillus strains isolated from rhizosphere showed plant growth promoting and antagonistic activity against phytopathogens. In Microbiological Research, vol. 167, no. 8, pp. 493 -499. DOI: 10.1016/j.micres.2012.05.002

KUMAR, S. - STECHER, G. - TAMURA, K. 2016. MEGA7: Molecular evolutionary genetics analysis version 7.0 for bigger datasets. In Molecular Biology and Evolution, vol. 33, no. 7, pp. $1870-1874$.

MAURHOFER, M. - KEEL, C. - HAAS, D. - DEFAGO, G. 1995. Influence of plant species on disease suppression by Pseudomonas fluorescens strain CHA0 with enhanced production. In Plant Pathology, vol. 44, no. 1, pp. 40-50. DOI: 10.1111/j.1365-3059.1995.tb02714.x

NAIK, P. - RAMAN, G. - NARAYANAN, K. - SAKTHIVEL, N. 2008. Assessment of genetic and functional diversity of phosphate solubilizing fluorescent pseudomonads isolated from rhizospheric soil. In BMC Microbiology, vol. 8, pp. 230. 
PAINTER, P.R. - MARR, A.G. 1968. Mathematics of microbial populations. In Annual Review of Microbiology, vol. 22 , pp. 519-548.

SANA, H. - ANJUM, T. - FATIMA, S. - ALI, A. - MAHBOOB, A. - AKRAM, W. 2014. Potential of some native Bacillus strains to promote growth of tomato. In Pakistan Journal of Biotechnology, vol. 11, no. 2, pp. 153-162.

SCHAAD, N.W. - JONES, J.B. - CHUN, W. 2001. Laboratory guide for the identification of plant pathogenic bacteria. St. Paul, MN : APS Press, pp.1-58.

SHIVAKUMAR, S. - BHAKTHAVATCHALU, S. -SULLIA, S.B. 2013. Characterization of multiple plant growth promotion traits of Pseudomonas aeruginosa FP6, a potential stress tolerant biocontrol agent. In $A n$ nals of Biological Research, vol. 4, no. 2, pp. 214-223.

SIVASAKTHI, S. - USHARANI, G. - SARANRAJ, P. 2014. Biocontrol potentiality of plant growth promoting bacteria (PGPR)-Pseudomonas fluorescens and Bacillus subtilis: a review. In African Journal of Agricultural Research, vol. 9, no. 16, pp. 1265-1277.

SICUIA, O.A. - GROSU, I. - CONSTANTINESCU, F. VOAIDES, C. - CORNEA, C.P. 2015. Enzymatic and genetic variability in Bacillus spp. strains with plant beneficial qualities. In Agrolife Scientific Journal, vol. 4, no. 2, pp. $124-131$

SILVA, H.S.A. - ROMEIRO, R.S. - MOUNTEER, A. 2003. Development of a root colonization bioassay for rapid screening of rhizobacteria for potential biocontrol agents. In Journal of Phytopathology, vol. 151, pp. 42-46.
STANIER, R.Y. - DOUDOROFF, M. - ADELBERG, E.A 1970. General microbiology. London, UK : Macmillan \& Co., Ltd, pp. 302-306.

STEIN, T. 2005. Bacillus subtilis antibiotics: structures, synthesis and specifics functions. In Molecular Microbiolo$g y$, vol. 56, pp. $845-857$.

TAMURA, K. - NEI, M. 1993. Estimation of the number of nucleotide substitutions in the control region of mitochondrial DNA in humans and chimpanzees. In Molecular Biology and Evolution, vol. 10, no. 3, pp. 512-526.

VESSEY, J.K. - BUSS, T.J. 2002. Bacillus cereus UW85 inoculation effects on growth, nodulation, and $\mathrm{N}$ accumulation in grain legumes: controlled-environment studies. In Canadian Journal of Plant Science, vol. 82, no. 2, pp. $282-290$.

WELLER, D.M. - COOK, R.J. 1983. Suppression of take-all of wheat by seed treatments with fluorescent Pseudomonads. In Phytopathology, vol. 73, pp. 463-469.

YOON, S.H. - HA, S.M. - KWON, S. - LIM, J. - KIM, Y. - SEO, H. - CHUN, J. 2017. Introducing EzBioCloud: A taxonomically united database of $16 \mathrm{~S}$ rRNA and whole genome assemblies. In International Journal of Systematic and Evolutionary Microbiology, vol. 67, pp. $1613-161$.

Received: February 2, 2019

Accepted: June 5, 2019 